\title{
Frederick Cancer Research and Development Center
}

National Cancer Institute

\section{Source}

National Cancer Institute. Frederick Cancer Research and Development Center. NCI

Thesaurus. Code C18801.

A government-owned, contractor operated cancer research facility located in Frederick, MD. Operated under the direction of the Division of Cancer Biology. 